\title{
ANALISIS KESTABILAN MODEL MATEMTIKA PENYEBARAN PENYAKIT BUSUK BUAH TANAMAN KAKAO AKIBAT JAMUR PHYTOPHTHORA PALMIVORA PADA KONDISI BEBAS PENYAKIT DAN ENDEMIK
}

\author{
R. A. Yahya1, R. Ratianingsih², dan Hajar ${ }^{3}$ \\ 1Program Studi Matematika Jurusan Matematika FMIPA Universitas Tadulako \\ Jalan Soekarno-Hatta Km. 09 Tondo, Palu 94118, Indonesia. \\ 1'obyyahya812@gmail.com, ${ }^{2}$ ratianingsih@yahoo.com, ${ }^{3}$ hajar.200490@yahoo.com
}

\section{ABSTRACT}

Fruit rot is one of cocoa plant disease. The disease is caused by the infection of Phytophthora palmivora, the fungus that carried by the ants as a vector. The spread of cocoa pod is caused by ants that carrying fungus and influenced by contact of specieses suscepted cocoa pods and ants. A mathematical SEI model that represents the spread of the disease was adapted such that classifies the populations as suscepted $\left(S_{h}\right)$, exposed $\left(E_{h}\right)$, and infected $\left(I_{h}\right)$ fruit. Suscepted $\left(S_{v}\right)$, and pathogens that carrying ants $\left(I_{v}\right)$ are also considered in the model, while the fungus population $(\mathrm{P})$ is assumed in a logistic model growth. The model obtained derived a free critical point $T_{1}=$ $\left(\frac{A_{h}}{\mu_{1}}, 0,0,0,0, \frac{A_{v}}{\mu_{4}}, 0\right)$ and a endemic critical point $T_{2}=\left(\begin{array}{c}\frac{A_{h} N_{h} \mu_{5}\left(D K+\mu_{4} N_{g}\right)}{\left(\mu_{1} N_{h} \mu_{5} D K+\mu_{1} N_{h} \mu_{4} \mu_{5} N_{g}+C D A_{v} K\right)}, \frac{\left.\delta C A_{h}\right)}{\left(\mu_{1} N_{h} \mu_{5} D K+\mu_{1} N_{h} D A_{4} \mu_{v} N_{g}+C D A_{v} K\right)\left(\mu_{2}+\delta\right)} \\ \frac{D A_{v} K}{\left(\mu_{1} N_{h} \mu_{5} D K+\mu_{1} N_{h} \mu_{4} \mu_{5} N_{g}+C D A_{v} K\right)\left(\mu_{2}+\delta\right) \mu_{3}}, K, \frac{A_{v} N_{g}}{D K r+\mu_{4} N_{g}}, \frac{D A_{v} K}{\left(D K r+\mu_{4} N_{g}\right) \mu_{5}}\end{array}\right)$. The stability of the model was analyzed by consider the eigenvalues of Jacobian matrix that evaluated at the endemic and free disease critical points. The research results shows that the free disease critical point is unstable, while the endemic critical point is stable. It could be stated that the free disease condition is temporary, while the spread of Phytophthora palmivora of is endemic.

Keywords : Analysis of Stability, Model SEI, Rotten Fruit Cocoa.

\section{ABSTRAK}

Busuk buah adalah salah satu penyakit pada tanaman kakao. Penyakit ini disebabkan oleh infeksi jamur Phytophthora Palmivora. Penyebaran busuk buah disebabkan oleh terbawanya jamur oleh semut sebagai vektor dan kontak antara semut pembawa jamur dengan buah kakao yang rentan. Model matematika yang merepresentasikan penyebaran penyakit tersebut diadaptasi dari model matematika SEI yang mengelompokkan sub populasi buah rentan Susceptible $\left(S_{h}\right)$, Exposed $\left(E_{h}\right)$, dan Infected $\left(I_{h}\right)$, sub populasi semut rentan $\left(S_{v}\right)$, sub populasi semut yang membawa patogen $\left(I_{v}\right)$ diperhatikan dalam model tersebut. Adapun populasi jamur sebagai patogen $(P)$ diasumsikan tumbuh mengikuti model logistik. Dari model tersebut diperoleh dua titik kritis yaitu $T_{1}=$ $\left(\frac{A_{h}}{\mu_{1}}, 0,0,0,0, \frac{A_{v}}{\mu_{4}}, 0\right)$ dan titik kritis endemik $T_{2}=\left(\begin{array}{c}\frac{A_{h} N_{h} \mu_{5}\left(D K+\mu_{4} N_{g}\right)}{\left(\mu_{1} N_{h} \mu_{5} D K+\mu_{1} N_{h} \mu_{4} \mu_{5} N_{g}+C D A_{v} K\right)}, \frac{C A_{h} D A_{v} K}{\left(\mu_{1} N_{h} \mu_{5} D K+\mu_{1} N_{h} \mu_{4} \mu_{5} N_{g}+C D A_{v} K\right)\left(\mu_{2}+\delta\right)} \\ \frac{\delta C A_{h} D A_{v} K}{\left(\mu_{1} N_{h} \mu_{5} D K+\mu_{1} N_{h} \mu_{4} \mu_{5} N_{g}+C D A_{v} K\right)\left(\mu_{2}+\delta\right) \mu_{3}}, K, \frac{A_{v} N_{g}}{D K r+\mu_{4} N_{g}}, \frac{D A_{v} K}{\left(D K r+\mu_{4} N_{g}\right) \mu_{5}}\end{array}\right)$. 
Model yang dibangun selanjutnya dianalis is kestabilannya dengan cara melihat nilai eigen dari matriks Jacobi yang dievaluasi pada titik kritis bebas penyakit dan endemik. Hasil penelitian menujukkan bahwa titik kritis bebas penyakit adalah tidak stabil, sedangkan titik kritis endemik adalah stabil. Hal ini menunjukkan bahwa kondisi bebas penyakit bersifat sementara, sedangkan kondisi endemik bersifat menetap.

Kata Kunci : Analisis Kestabilan, Model SEI, Busuk Buah Kakao.

\section{PENDAHULUAN}

Tanaman Kakao di Indonesia merupakan salah satu komoditi perkebunan yang penting,karena merupakan bahan baku industri yang dapat meningkatkan devisa negara dan pendapatan parapetani kakao. Data Badan Pusat Statistik (2003) menunjukkan bahwa, luas areal perkebunan kakao di Sulawesi Tengah pada tahun 2001 mencapai 79.161 ha dengan produksi 111.554 ton dan padatahun 2002 meningkat mencapai 114.906 ha dengan produksi 113.731 ton, selanjutnya pada tahun 2003 luas areal perkebunan kakao terus meningkat mencapai 122.817 ha dengan produksi rata -rata 113.218 ton. Hal ini menunjukan antusias masyarakat/petani terhadap budidaya kakao sangat tinggi, sehingga tanaman kakao mem punyai prospek yang cukup bagus dan dapat memberikan kontribusi yang sangat besar. Peningakatan produksi kakao dapat menurun dikarenakan adanya penyakit pada buah kakao yang sering dikenal dengan penyakit busuk buah pada buah kakao.

Penyakit busuk buah yang disebabkan oleh jamur Phytophthora palmivora adalah salah satu penyakit yang sangat berbahaya pada tanaman kakao. Phytophthora palmivora adalah salah satu patogen yang menyerang buah kakao, patogen berkembang didalam tanah dan mampu hidupselama berbulan-bulan dalam tanah (Semangun, 1996). Salah satu penyebab penyebaran penyakitbusuk buah yang disebabkan oleh jamur Phytophthora palmivora yaitu semut Iridomyrmex cordatus, semut Iridomyrmex cordatus adalah jenis semut yang hidup di tanaman kakao, semut tersebut mampu mempercepat penyebarkan penyakit busuk buah pada buah kakao dalam waktu beberapa hari (Rosmana, dkk. 2010).

Alur penyebaran penyakit busuk buah pada tanaman kakao dimulai dari kelompok buahkakao rentan yang memasuki masa exposed akibat kontak langsung antara buah yang sehat dengan buah yang terinfeksi maupun perantara binatang yaitu semut. Buah exposedakan menjadi buah infected ketika ketahanan buah kakao menurun kemudian setelah buah kakao terinfeksi. Buah kakao yang terinfeksi jamur Phytophthora palmivora tidak dapat kembali sehat karena langsung membusuk.

Penelitian ini mengkaji penyebaran penyakit busuk buah pada tanaman kakao melalui model epidemik SEI. Dalam model tersebut populasi buah kakao dibagi menjadi 3 kelom pok yaitu kelompok buah kakao yang rentan (Susceptible), kelom pok buah kakao yang terinfeksi penyakit tapi belum bisa menginfeksi (Exposed), dan kelompok buah kakao yang terinfeksi dan tidak dapat sembuh dari penyakit (Infected). Kelom pok populasi semut terbagi atas sub populasi semut yang tidak membawa patogen dan populasi semutyang membawa patogen. Adapun pertumbuhan populasi Phytophthora 
palmivora yang berkurang karena terbawa oleh semut dan pengaruh daya dukung lingkungan dinyatakan dalam suatu pertumbuhan logistik. Model yang telah dibangun selanjutnya diuji kestabilannya dititik kritis bebas penyakit dan titik kritis endemik dengan menggunakan metode Linearisasi.

\section{METODE PENELITIAN}

a. Memulai penelitian.

b. Mengkaji literatur untuk membangun model penyebaran penyakit busuk buah yangdisebabkan oleh jamur Phytophthora palmivora pada tanaman kakao.

c. Membangun model penyebaran penyakit busuk buah yang disebabkan oleh jamur Phytophthora palmivora pada tanaman kakao.

d. Menyelesaikan model tentang penyebaran penyakit busuk buah yang disebabkan oleh jamur Phytophthora palmivora pada tanaman kakao.

- Langkah pertama yaitu menentukan titik kritis, selanjutnya melakukan transformasi karena titik kritis yang diperoleh bukan titik kritis nol.

- $\quad$ Langkah kedua melakukan linearisasi menggunakan matriks Jacobi.

Linierisasi adalah proses ham piran persamaan differensial tak linier dengan persamaan differensial linier. Linierisasi digunakan untuk menyelesaikan sistem autonomus yang berbentuk:

$$
\begin{aligned}
& \frac{d x}{d t}=f(x, y) \\
& \frac{d y}{d t}=g(x, y)
\end{aligned}
$$

Dimana $f$ dan $g$ adalah fungsi tak linier. Pada sistem persamaan (2.1) dan (2.2)dapat diperoleh titik kritis jika $f\left(x_{0}, y_{0}\right)=0$ dengan $\left(x_{0}, y_{0}\right)$ adalah titik kritis dan $f(x, y)$ adalah persamaan diferensial yang autonomous maka :

$$
\begin{aligned}
& f\left(x_{0}, y_{0}\right)=0 \\
& g\left(x_{0}, y_{0}\right)=0
\end{aligned}
$$

(Olsder, 2003)

Notasi matriks sangat efektif digunakan untuk menyelesaikan persamaan linier, matiks yang elemen-elemennya merupakan turunan pertama disebut matrik Jacobi.

$$
\text { Matriks Jacobi }=\left[\begin{array}{ll}
\frac{d f}{d x} & \frac{d f}{d y} \\
\frac{d g}{d x} & \frac{d g}{d y}
\end{array}\right] .
$$

Sebuah matriks dievaluasi pada titik kesetimbangan $x=x_{0} \quad y=y_{0}$. Pergantian matriks dari titik kesetimbangan adalah $\bar{r}=\left[\begin{array}{l}u \\ v\end{array}\right]=\left[\begin{array}{l}x-x_{0} \\ y-y_{0}\end{array}\right]$, sehingga persamaan dapat ditulis 
menjadi $\frac{d r}{d t}=A \bar{r}$ dimana $A$ adalah matriks konstan yang diperoleh dari matriks Jacobi yang dievaluasi dititik kritisnya:

$$
A=\left[\begin{array}{ll}
f_{x}\left(x_{0}, y_{0}\right) & f_{y}\left(x_{0}, y_{0}\right) \\
g_{x}\left(x_{0}, y_{0}\right) & g_{y}\left(x_{0}, y_{0}\right)
\end{array}\right]=\left(\begin{array}{ll}
a & c \\
b & d
\end{array}\right)
$$

(Campbell \& Haberman, 2008).

Menurut Campbell dan Haberman (2008), jika salah satu akar polinom karakteristik bernilai nol dan akar lainnya bernilai positif maka sistem nonlinier tidak stabil. Jika salah satu akar polinom karakteristik bernilai nol dan akar lainnya bernilai negatif maka sistem nonlnier dapat stabil atau tidak stabil bergantung pada unsur nonlinier yang diabaikan.

e. Menginterprestasikan model penyebaran penyakit busuk buah yang disebabkan oleh jamur Phytophthora palmivora pada tanaman kakao.

\section{HASIL DAN PEMBAHASAN}

\subsection{Model Matematika Penyebaran Penyakit busuk buah kakao}

\subsubsection{Model Matematika Penyebaran Penyakit busuk buah kakao}

Dalam penelitian ini penyebaran penyakit busuk buah pada tanaman kakao dibangun berdasarkan asumsi - asumsi dan diadaptasi dari model SEI, sebingga Gambaran perpindahan kelom pok populasi buah kakao dan interaksinya dengansemut dan jamur Phytophthora palmivora dinyatakan dalam diagram transfer pada Gambar1.

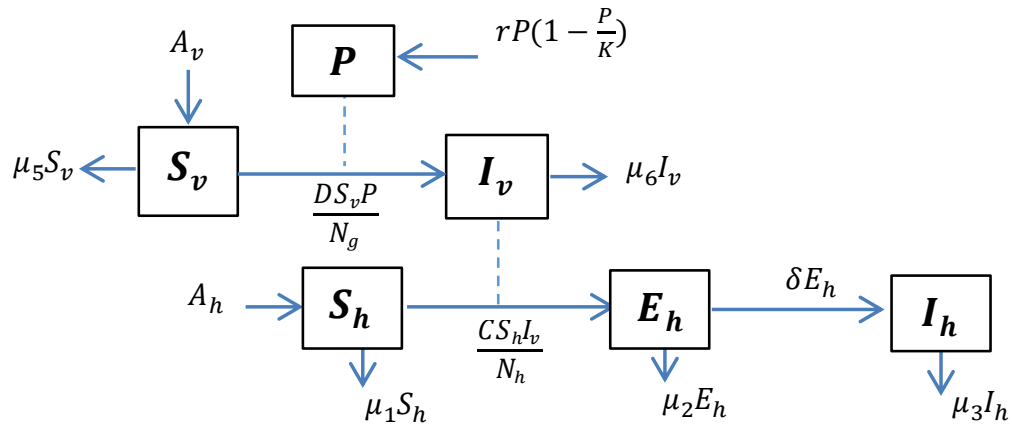

Gambar 1: Alur Penyebarain Penyakit Busuk Huah Pada Tanaman Kakao

Rangkaian proses pertumbuhan, kematian dan interaksi antar subpopulasi tersebut dinyatakan dalam sistem persamaan diferensial sebagai berikut

$$
\frac{d S_{h}}{d t}=A_{h}-\mu_{1} S_{h}-\frac{C S_{h} I_{v}}{N_{h}}
$$




$$
\begin{aligned}
& \frac{d E_{h}}{d t}=\frac{C S_{h} I_{v}}{N_{h}}-\mu_{2} E_{h}-\delta E_{h} \\
& \frac{d I_{h}}{d t}=\delta E_{h}-\mu_{3} I_{h} \\
& \frac{d P}{d t}=r P\left(1-\frac{P}{K}\right) \\
& \frac{d S_{v}}{d t}=A_{v}-\frac{D S_{v} P}{N_{g}}-\mu_{4} S_{v} \\
& \frac{d I_{v}}{d t}=\frac{D S_{v} P}{N_{g}}-\mu_{5} I_{v}
\end{aligned}
$$

\subsubsection{Menentukan Titik Kritis}

Dari model yang dinyatakan dalam persamaan (3.1.a) - (3.1.f) diperoleh dua titk kritis, yaitu titik kritis bebas penyakit $\left(T_{1}\right)$ dan titik kritis endemik $\left(T_{2}\right)$. Titik kritis $\left(T_{1}\right)$ diperoleh dari persamaan (3.1a), (3.2b), (3.3e) dan (3.1f) untuk nilai $P=0$ dengan $\frac{d S_{h}}{d t}=0, \frac{d E_{h}}{d t}=0, \frac{d I_{h}}{d t}=0, \frac{d P}{d t}=0, \frac{d S_{v}}{d t}=0, \frac{d I_{v}}{d t}=0$ sehingga diperoleh titik kritis $T_{1}=$ $\left(\frac{A_{h}}{\mu_{1}}, 0,0,0,0, \frac{A_{v}}{\mu_{4}}, 0\right)$, sedangkan untuk $P \neq 0$ maka diperoleh titik kritis $T_{2}=$ $\left(\begin{array}{c}\frac{A_{h} N_{h} \mu_{5}\left(D K+\mu_{4} N_{g}\right)}{\left(\mu_{1} N_{h} \mu_{5} D K+\mu_{1} N_{h} \mu_{4} \mu_{5} N_{g}+C D A_{v} K\right)}, \frac{C A_{h} D A_{v} K}{\left(\mu_{1} N_{h} \mu_{5} D K+\mu_{1} N_{h} \mu_{4} \mu_{5} N_{g}+C D A_{v} K\right)\left(\mu_{2}+\delta\right)}, \\ \frac{\delta C A_{h} D A_{v} K}{\left(\mu_{1} N_{h} \mu_{5} D K+\mu_{1} N_{h} \mu_{4} \mu_{5} N_{g}+C D A_{v} K\right)\left(\mu_{2}+\delta\right) \mu_{3}}, K, \frac{A_{v} N_{g}}{D K r+\mu_{4} N_{g}}, \frac{D A_{v} K}{\left(D K r+\mu_{4} N_{g}\right) \mu_{5}}\end{array}\right)$.

\subsubsection{Analisa Kestabilan di sekitar Titik Kritis}

a. Kestabilan sistem di titik kritis $\left(T_{1}\right)$

Titik kritis pertama merupakan titik kritis bebas penyakit. Kestabilan di titik kritis tersebut diperoleh berdasarkan nilai eigen dari Matriks Jacobi yang diperoleh dari linearisasi model. Titik kritis $\left(T_{1}\right)$ dan $\left(T_{2}\right)$ bukan titik kritis nol maka terlebih dahulu dilakukan transformasi.

Pada titik kritis $\left(T_{1}\right)$ matriks Jacobi yang dievaluasi di titik kritis baru diperoleh sebagai berikut:

$$
J a_{1}=\left[\begin{array}{cccccc}
-\mu_{1}-\lambda & 0 & 0 & 0 & 0 & 0 \\
0 & -\mu_{2}-\delta-\lambda & 0 & 0 & 0 & 0 \\
0 & \delta & -\mu_{3}-\lambda & 0 & 0 & 0 \\
0 & 0 & 0 & r-\lambda & 0 & 0 \\
0 & 0 & 0 & 0 & -\mu_{4}-\lambda & 0 \\
0 & 0 & 0 & 0 & 0 & -\mu_{5}-\lambda
\end{array}\right]
$$

diperoleh solusi dari persamaan karakteristiknya berupa nilai eigen sebagai berikut:

$$
\lambda_{1}=-\mu_{1} \quad \lambda_{2}=-\mu_{2}-\delta \quad \lambda_{3}=-\mu_{3}
$$


$\lambda_{4}=r$

$\lambda_{5}=-\mu_{4}$

$\lambda_{6}=-\mu_{5}$

Meskipun $\lambda_{1}, \lambda_{2}, \lambda_{3}, \lambda_{5}$ dan $\lambda_{6}$ bernilai negatifnamun $\lambda_{4}>0$ memberikan artisistem tidak stabil dititik kritis $T_{1}$.

b. Kestabilan sistem di titik kritis $\left(T_{2}\right)$

Pada titik kritis kedua $\left(T_{2}\right)$ merupakan titk kritis endemik. Nilai eigen matriks $J a_{2}$ diperoleh dari solusi persamaan karakteristik $\operatorname{det}\left(J a_{2}-\lambda I\right)=0$

$$
\operatorname{Det}=\left[\begin{array}{cccccc}
-\mu_{1}-\frac{C D A_{v} K}{\left(D K+\mu_{4} N_{g}\right) \mu_{5} N_{h}}-\lambda & 0 & 0 & 0 & 0 & -\frac{C A_{v} \mu_{5}\left(D K+\mu_{4} N_{g}\right)}{\mu_{1} N_{h} \mu_{5} D K+\mu_{1} N_{h} \mu_{4} \mu_{5} N_{g}+C D A_{v} K} \\
\frac{C D A_{v} K}{\left(D K+\mu_{4} N_{g}\right) \mu_{5} N_{h}} & -\mu_{2}-\delta-\lambda & 0 & 0 & 0 & \frac{C A_{v} \mu_{5}\left(D K+\mu_{4} N_{g}\right)}{\mu_{1} N_{h} \mu_{5} D K+\mu_{1} N_{h} \mu_{4} \mu_{5} N_{g}+C D A_{v} K} \\
0 & \delta & -\mu_{3}-\lambda & 0 & 0 \\
0 & 0 & 0 & -r-\lambda & 0 & 0 \\
0 & 0 & 0 & -\frac{D A_{v}}{D K+\mu_{4} N_{g}} & -\frac{D K}{N_{g}}-\mu_{4}-\lambda & -\mu_{5}-\lambda
\end{array}\right]
$$

Dalam bentuk polinom, persamaan karakteristik untuk matriks $\mathrm{Ja}_{2}$ adalah

$$
\frac{1}{N_{g}\left(D K+\mu_{4} N_{g}\right) \mu_{5 N_{h}}}\left((-r-\lambda)\left(D K+\mu_{4} N_{g}+\lambda N_{g}\right)\left(-\mu_{5}-\lambda\right)\left(\mu_{1} N_{h} \mu_{5} D K+\mu_{1} N_{h} \mu_{5} \mu_{4} N_{g}+C A_{v^{i}}\right) K\right.
$$

Dari persamaan (6) nilai eigennya yaitu:

$$
\begin{array}{lll}
\lambda_{1}=-r & \lambda_{2}=-\frac{D K+\mu_{4} N_{g}}{N_{g}} & \lambda_{3}=-\mu_{5} \\
\lambda_{4}=-\frac{\mu_{1} N_{h} \mu_{5} D K+\mu_{1} N_{h} \mu_{5} \mu_{4} N_{g}+C A_{v} D K}{N_{g}\left(D K+\mu_{4} N_{g}\right)} & \lambda_{5}=-\mu_{2}-\delta & \lambda_{6}=-\mu_{3}
\end{array}
$$

Nilai $\lambda_{1}, \lambda_{2}, \ldots, \lambda_{6}$ yang bernilai negatif tersebut menunjukkan bahwa titik kritis endemik adalah stabil.

\subsubsection{Simulasi Model}

a. Simulasi Model $\left(T_{1}\right)$

Model penyebaran penyakit busuk buah pada tanaman kakao dilakukandengan menggunakan program Maple13 dengan menggunakan nilai - nilai parameter pada Tabel 5.

Tabel 5 : Nilai-nilai Parameter pada Model Penyebaran Penyakit Busuk Buah Kakao

\begin{tabular}{|c|l|c|c|}
\hline Parameter & \multicolumn{1}{|c|}{ Keterangan } & Nilai & Sumber \\
\hline$A_{h}$ & Laju pertum buhan populasi buah kakao & 1000 & Asumsi \\
\hline$A_{v}$ & Laju kelahiran populasi semut & 1000 & Asumsi \\
\hline$\mu_{h}$ & Laju Kematian alami pada buah kakao & 0,0668 & $\frac{1}{\text { life time }}$ \\
\hline
\end{tabular}




\begin{tabular}{|c|l|c|c|}
\hline$\delta$ & $\begin{array}{l}\text { Laju transisi dari kompartemen buah yang } \\
\text { terinfeksi namun belum mampu mengifeksi } \\
\text { ke buah terinfeksi }\end{array}$ & 0,83 & Asumsi \\
\hline$\mu_{v}$ & Laju Kematian alami pada semut & 0,05 & Asumsi \\
\hline $\mathrm{C}$ & $\begin{array}{l}\text { Peluang kontak antara buah rentan dan } \\
\text { semut yang membawa patogen }\end{array}$ & 0,6 & Asumsi \\
\hline $\mathrm{D}$ & $\begin{array}{l}\text { Peluang kontak antara semut dan } \\
\text { patogen }\end{array}$ & 0,9 & Asumsi \\
\hline $\mathrm{R}$ & Laju kelahiran alami pathogen & 0,006 & Asumsi \\
\hline $\mathrm{K}$ & Carryng capacity & 2000 & Asumsi \\
\hline
\end{tabular}

Simulasi untuk titik kritis bebas penyakit dilakukan dengan menggunakannilai awal $S_{h}(0)=0, E_{h}(0)=0, I_{h}(0)=0, P(0)=0, S_{v}(0)=1000, I_{v}(0)=0$ dengan waktu pengamatan selama 150 hari. Gambar 2. memperlihatkan bahwa sub populasi buah rentan dan semut akan terus mengalami peningkatan. Keadaan yang menggambarkan populasi terbebas dari penyakit tergambar dari ketidakberadaan sub populasi lain seiring dengan pertambahan waktu.

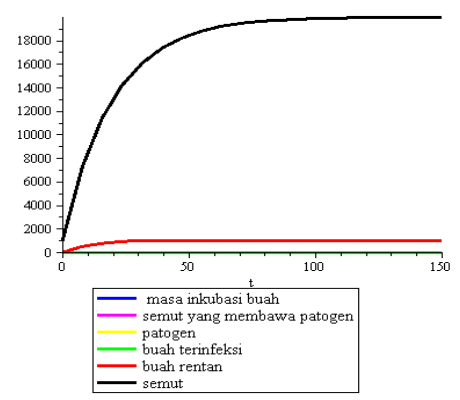

Gambar 2: Laju Perubahan Populasi Buah Rentan Dan Semut

b. Simulasi Model $\left(T_{2}\right)$

Simulasi Simulasi untuk titik kritis en dem ik diperoleh dengan menggunakannilai $\operatorname{awal}_{h}(0)=500, E_{h}(0)=300, I_{h}(0)=200, P(0)=1800, S_{v}(0)=1000, I_{v}(0)=900$ dengan interval waktu selama 150 hari ditunjukkan pada Gambar 3. 


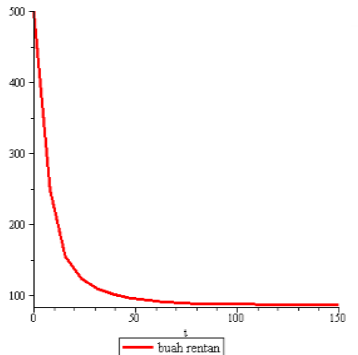

(3a)

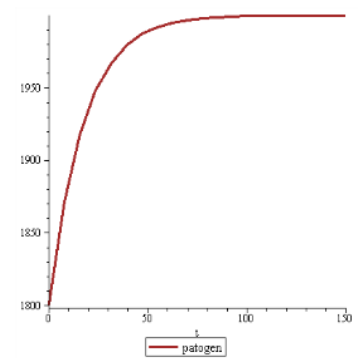

(3d)

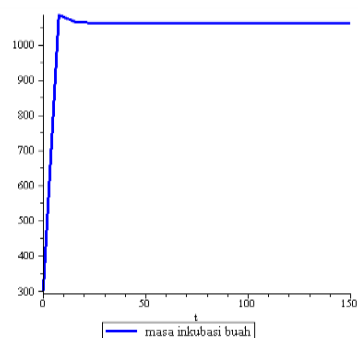

(3b)

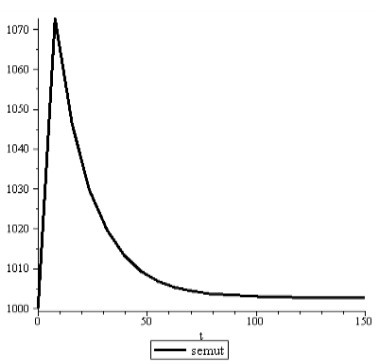

(3e)

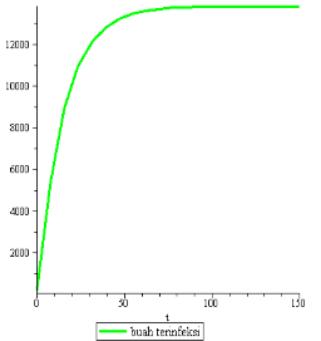

(3c)

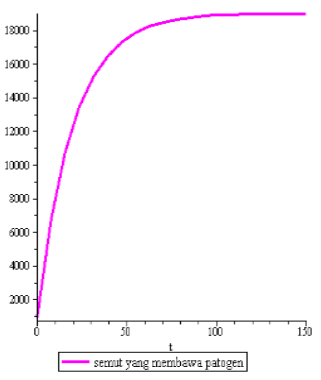

(3f)

Gambar 3 : Laju Perubahan Populasi Buah Rentan, Patogen Dan Semut Terhadap Waktu.

Gambar (3a) memperlihatkan terjadinya penurunan banyaknya populasi rentan dan pada akhirnya mendekati konstan setelah waktu tertentu, Gambar (3b) menunjukkan bahwa terjadi peningkatan populasi buah coklat yang memasuki masa inkubasi sampai 1070 buah, kemudian terjadi penurunan dan mendekati konstan setelah waktu tertentu, pada Gambar (3c) menunjukkan tingkai infeksi buah yang terinfeksi terus mengalami kenaikan dan pada akhirnya mendekati konstan setelah waktu tertentu. Gambar (3d) menunjukkan kenaikan populasi patogen akibat laju pertumbuhan pada patogen dan mendekati konstan setelah waktu tertentu, Gambar (3e) menunjukkan bahwa terjadi kenaikan populasi semut hingga 1080 ekor dan pada hari ke 10 terjadi penurunan akibat kontak antara populasi patogen dan berkurang karena kematian alami dan pada akhirnya mendekati konstan setelah waktu tertentu, Gambar (3f) menunjukkan kenaikan populasi semut yang membawa patogen karena kontak antara populasi patogen dan mendekati konstan setelah waktu tertentu.

\section{KESIMPULAN}

1. Model matematika penyebaran penyakit busuk buah pada tanaman kakao adalah model matematika SEI sebagai berikut:

$$
\frac{d S_{h}}{d t}=A_{h}-\mu_{1} S_{h}-\frac{C S_{h} I_{v}}{N_{h}}
$$




$$
\begin{aligned}
\frac{d E_{h}}{d t} & =\frac{C S_{h} I_{v}}{N_{h}}-\mu_{2} E_{h}-\delta E_{h} \\
\frac{d I_{h}}{d t} & =\delta E_{h}-\mu_{3} I_{h} \\
\frac{d P}{d t} & =r P\left(1-\frac{P}{K}\right) \\
\frac{d S_{v}}{d t} & =A_{v}-\frac{D S_{v} P}{N_{g}}-\mu_{4} S_{v} \\
\frac{d I_{v}}{d t} & =\frac{D S_{v} P}{N_{g}}-\mu_{5} I_{v}
\end{aligned}
$$

2. Pada model penyebaran penyakit busuk buah tanaman diperoleh dua titik kritis yaitu:

a. Titik kritis bebas penyakit $\left(T_{1}\right)$

$$
T_{1}=\left(\frac{A_{h}}{\mu_{1}}, 0,0,0,0, \frac{A_{v}}{\mu_{4}}, 0\right)
$$

b. Titik kritis endemik $\left(T_{2}\right)$

$$
T_{2}=\left(\begin{array}{c}
\left.\frac{A_{h} N_{h} \mu_{5}\left(D K+\mu_{4} N_{g}\right)}{\left(\mu_{1} N_{h} \mu_{5} D K+\mu_{1} N_{h} \mu_{4} \mu_{5} N_{g}+C D A_{v} K\right)}, \frac{C A_{h} D A_{v} K}{\left(\mu_{1} N_{h} \mu_{5} D K+\mu_{1} N_{h} \mu_{4} \mu_{5} N_{g}+C D A_{v} K\right)\left(\mu_{2}+\delta\right)}\right) \\
\frac{\delta C A_{h} D A_{v} K}{\left(\mu_{1} N_{h} \mu_{5} D K+\mu_{1} N_{h} \mu_{4} \mu_{5} N_{g}+C D A_{v} K\right)\left(\mu_{2}+\delta\right) \mu_{3}}, K, \frac{A_{v} N_{g}}{D K r+\mu_{4} N_{g}}, \frac{D A_{v} K}{\left(D K r+\mu_{4} N_{g}\right) \mu_{5}}
\end{array}\right)
$$

3. Simulasi penyebaran penyakit busuk buah pada suatu model SEI dalam penelitian ini menunjukkan fenomena bebas penyakit dan endemik. Simulasi keadaan bebas penyakit memperlihatkan bahwa pada populasi buah rentan dan semut akan terus mengalami peningkatan hingga akhirnya mendekati konstan setelah waktu tertentu. Sedangkan simulasi keadaan endemik mem perlihatkan bahwa penyakit busuk buah bersifat menetappadapopulasi buah kakao. Hal ini menunjukkan terjadinya penyebaran patogen yaitu jamur Phytophthora palmivora terjadi secara terus menerus akibat terbawa oleh semut.

\section{DAFTAR PUSTAKA}

[1] Badan Pusat Statistik Provinsi Sulawesi Tengah, Bps.go.id, 2003, [Online]. http://sulteng.bps.go.id/frontend/linkTabelStatis/view/id/305.

[2] Campbell, S.L., \& Haberman, R, Introduction to Differensial Equitions with Dinamycal System. New Jersey: Princeton University Pres, 2008.

[3] Olsder, G.J, Mathematical System Theory, 2003, Delft, The Natherland.

[4] Rosmana, dkk, Peranan Semut Iridomirmex cordatus (Hyminoptera:Formicidae) dalam Menularkan Patogen Busuk Buah Phytophthora palmivora, Pelita Perkebunan 2010, 26(3), 169-176.

[5] Semangun, H, IImu Penyakit Tumbuhan. Gadjah Mada University Press, 1996, Yogyakarta. 